\title{
A Case of Hypereosinophilic Syndrome Presenting with Multiorgan Thromboses Associated with Intestinal Obstruction
}

\section{Intestinal Tıkanıklı ile İlişkili Multiorgan Yetmezliği ile Başvuran Bir Hipereozinofilik Sendrom Olgusu}

\author{
Tao Sui ${ }^{1}$, Qing $\mathrm{Li}^{1}{ }^{*}$, Li Gengl, Xinnv $\mathrm{Xu}^{2}$, Yuming $\mathrm{Li}^{1}$ \\ ${ }_{1}^{1}$ Department of Hematology, Tianjin First Center Hospital, Tianjin, China \\ ${ }^{2}$ Key Lab for Critical Care Medicine of the Ministry of Health, Tianjin First Center Hospital, Tianjin, China \\ *This author contributed equally to this work and should be considered as co-first author
}

\begin{abstract}
:
Idiopathic hypereosinophilic syndrome (HES) is a disease characterized by persistent hypereosinophilia $(>1.5 \times 109 / \mathrm{L})$ for more than 6 months in the absence of other causes of reactive eosinophilia. Patients with HES presenting with multiorgan thromboses are rare. Herein we report a 57-year-old man with HES who presented with deep venous thrombosis of the lower extremities, portal thrombosis, pulmonary embolism, and mesenteric venous thrombosis, which led to intestinal obstruction.
\end{abstract}

Key Words: Eosinophilia, Hypereosinophilic syndrome, Thrombosis, Intestinal obstruction

Özet:

İdiyopatik hipereozinofilik sendrom (HES) reaktif eozinofilinin diğer nedenlerinin yokluğunda 6 aydan uzun süren persistan eozinofili (>1.5×109/L) ile karakterize bir hastalıktır. Multiorgan trombozları ile başvuran HES'li olgular nadirdir. Burada, alt ekstremite derin ven trombozu, portal tromboz, pulmoner embolizm, ve özellikle intestinal tıkanıklığa yol açan mezenterik venöz tromboz ile başvuran 57 yaşında bir erkek olgu sunulmuştur.

Anahtar Sözcüikler: Eozinofili, Hipereozinofilik sendrom, Tromboz, Intestinal tıkanıklık

\section{Introduction}

Idiopathic hypereosinophilic syndromes (HESs) are rare disorders that comprise a heterogeneous group of diseases characterized by unexplained persistent, nonreactive overproduction of eosinophils $(>1.5 \times 109 / \mathrm{L})$ persistent for more than 6 months. HES can cause multiple organ damage/dysfunction, mainly involving the skin, heart, lung, gastrointestinal tract, and nervous system [1].
The clinical manifestations of HES include fever, rash, fatigue, cough, shortness of breath, muscle aches, and diarrhea. The most common presenting manifestation is thrombosis, such as mural thrombus of the heart, inferior vena cava thrombosis, superficial venous thrombosis, portal thrombosis, deep venous thrombosis, cerebral arteriolar and venous thrombosis, and intracardiac thrombi [2, $3,4,5]$. Simultaneous multiple organ thromboses associated with HES rare. Herein, we report a unique case of HES

Address for Correspondence: Tao SUI, M.D.

Department of Hematology, Tianjin First Center Hospital, 24\# Fukang Road, Nankai District, Tianjin 300192, China

Phone: +8622 23626519 E-mail: taosui71@yahoo.com.cn 
presenting with deep venous thrombosis of the lower extremities, portal thrombosis, pulmonary embolism, and especially mesenteric venous thromboembolism, which led to intestinal obstruction.

\section{Case Report}

A 57-year-old man was admitted to our department for pain and swelling of both lower extremities accompanied with fever for more than 10 days. His medical and family histories were unrevealing. His vital signs were within the normal range and the clinical examination was normal, except for hyperemia, warmth, slight tenderness, and edema of both lower legs, especially in the right leg. White blood cell count was high $\left(23.9 \times 10^{9} / \mathrm{L}\right)$ with $66.5 \%$ eosinophils (15.9 $\times 109 / \mathrm{L}$ ), hemoglobin of $141 \mathrm{~g} / \mathrm{L}$, and thrombocytopenia of $11 \times 109 / \mathrm{L}$. Liver and renal function tests were normal. A test for parasites in the stool and serum was negative. Tests for tumor markers were negative. The work-up for allergic and rheumatologic diseases were also negative (including anti-nuclear, anti-dsDNA, anti-neutrophilic cytoplasmic antibodies; anti-phospholipid antibodies; anti-SSA, antiSSB, anti-histone antibodies). A bone marrow aspiration and biopsy were performed and hematological malignancies were excluded. The bone marrow aspiration revealed a significant proliferation of trilineage cells and a prominent component of mature-appearing eosinophils comprising $68 \%$ of the total cellularity. The bone marrow biopsy showed normal cellularity with increased eosinophils. Polymerase chain reaction indicated a negative BCR-ABL while fluorescence in situ hybridization indicated a negative FIP1L1-PDGFRA gene fusion. An ultrasound confirmed the arteriosclerosis of both lower limbs accompanied by multiple plaques and thrombosis of the right popliteal vein. An abdominal ultrasound revealed fatty liver and thrombosis of the portal vein. Echocardiography showed that the patient's atrioventricular cavity size, ventricular wall thickness, range of motion, and valve morphology were all normal. Ejection fraction was 69\%.

At this stage, HES with multiorgan thromboses was suspected. Methylprednisolone (40 mg/day) was commenced and piperacillin was initiated, empirically. Hemorrhagic spots appeared on the skin of both lower limbs, and blood blisters of the oral mucosa were observed at a certain period. Thus, platelets were transfused.Pain and swelling of both lower extremities were alleviated using the aforementioned treatment. At day 10, abdominal distension and abdominal pain occurred and the abdominal pain could not be relieved by anisodamine hydrochloride. It gradually worsened and abdominal tenderness emerged with rebound tenderness as well as muscle tension. A plain abdominal radiograph revealed intestinal obstruction. No neurologic abnormalities were noted. White blood cell count was $8.07 \times 109 / \mathrm{L}$ with $26.2 \%$ eosinophils $(2.12 \times 109 / \mathrm{L}), 107$ g/L hemoglobin, and $18 \times 10^{9} / \mathrm{L}$ platelets. No evident presence of fragmented red blood cells was observed in the peripheral smear. The renal function was normal and The prothrombin time (PT) was $18.2 \mathrm{~s}$ and the activated partial thromboplastin time (aPTT) was 40.9 s. Fibrinogen was 8.1 $\mathrm{g} / \mathrm{L}$ and D-dimer was $9.6 \mu \mathrm{g} / \mathrm{mL}$. Computed tomography (CT) results suggested that for the thrombosis of the superior mesenteric vein (Figure 1), emergency partial excision of the small intestine could be performed. The histopathological investigation confirmed the extensive small bowel hemorrhage, necrosis, and mesenteric vascular thrombosis. Postoperative recovery was good. Continued treatment with glucocorticoid and anticoagulant therapy was not performed due to the patient's very low platelet counts with higher risk of bleeding. On day 29, the patient had dyspnea and breath-holding accompanied by chest pain and intermittent expectoration with bloody streaks. Oxygen saturation was $85 \%$ without oxygen support. Auscultation of the lungs revealed moist rales. Pulmonary CT angiography showed embolism in the bilateral pulmonary arteries and their branches, as well as bilateral pleural effusion (Figure 2). Meanwhile, protein $\mathrm{C}$ and $\mathrm{S}$ levels were normal.

An ultrasound of the abdomen and both lower limbs showed that the thrombosis of the right popliteal vein and portal vein had no significant alteration compared with
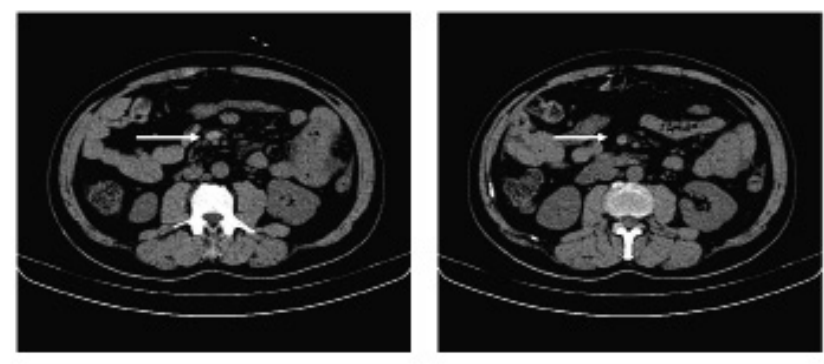

Figure 1: CT showing the thrombosis of the superior mesenteric vein (arrow).
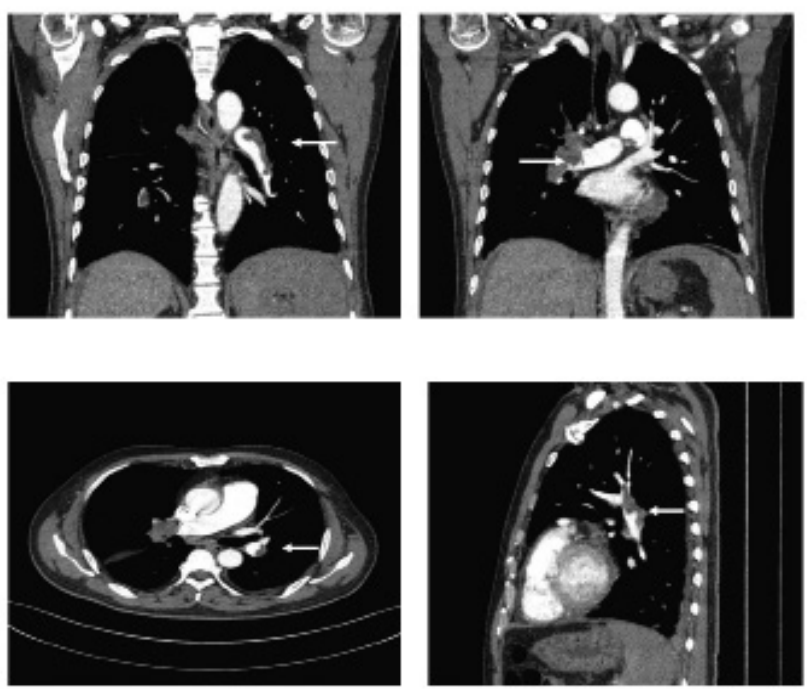

Figure 2: Pulmonary CT angiography showing embolism in the pulmonary arteries and their branches (arrow). 
previous images. The white blood cell count was $8.69 \times 109 / \mathrm{L}$, with $31.3 \%$ eosinophils $(2.72 \times 109 / \mathrm{L}), 90 \mathrm{~g} / \mathrm{L}$ hemoglobin, and $21 \times 109 / \mathrm{L}$ platelets. The PT was $17.9 \mathrm{~s}$ and the APTT was $57.6 \mathrm{~s}$. Fibrinogen was $2.43 \mathrm{~g} / \mathrm{L}$ and D-dimer was 2.6 $\mu \mathrm{g} / \mathrm{mL}$. Heparin (2000 IU/day) was initiated. Platelets were transfused when the counts were lower than $10 \times 109 / \mathrm{L}$. On day 35, the patient's eosinophil count returned to normal; the white blood cell count was $6.68 \times 109 / \mathrm{L}$ with $0.2 \%$ eosinophils $\left(0.02 \times 10^{9} / \mathrm{L}\right)$, hemoglobin of $90 \mathrm{~g} / \mathrm{L}$, and platelets of $19 \times 10^{9} / \mathrm{L}$. The patient's condition also gradually stabilized. CT showed that the pulmonary embolism was significantly improved in compared with the previous images. Prednisone $(28 \mathrm{mg} /$ day $)$ and coumadin $(2.5 \mathrm{mg} /$ day) were initiated. Thus far, follow-up has been consistent; the eosinophil and platelet counts were within normal limits and no recurrence of thrombosis was observed. Informed consent was obtained.

\section{Discussion}

HES is a rare hematological disorder, and its diagnosis is set when patients have persistently elevated eosinophil counts of $>1.5 \times 109 / \mathrm{L}$ for more than 6 months and other causes of reactive eosinophilia have been excluded through histopathological evaluation and imaging studies for internal organ involvement.

Our patient was FIP1L1-PDGFRA-negative and did not show any evidence of $\mathrm{T}$ or B cell clonality. The diagnosis of idiopathic HES was considered after asthma, eczema, parasitic infestation, autoimmune disorders, and malignant neoplasm were ruled out. However, hereditary thrombophilia cannot be excluded due to the fact that hereditary factors such as factor V Leiden mutation, prothrombin G20210 mutation, and AT deficiency were not investigated. To the best of our knowledge, multiorgan thromboses, as a presentation of HES especially associated with intestinal obstruction, is rare and have only been reported by Kobayashi et al. [6] .

When our patient presented with venous thrombosis of both legs, the portal vein, and the superior mesenteric vein, anticoagulation was not performed due to the severe thrombocytopenia accompanied with mucosal bleeding. Glucocorticoids and platelet transfusions were preferred. The eosinophil counts gradually decreased, suggesting that our patient exhibited response to glucocorticoids. However, unfortunately the patient developed pulmonary embolism. Initially, we assumed that the embolism was related to thrombus shedding, and so an ultrasound was performed again. The images showed that the thrombosis of the right popliteal vein and the portal vein had no significant alteration compared to previous images. Pulmonary CT angiography showed multiple embolism in the pulmonary arteries. Thus, the pulmonary embolism may have been due to local eosinophilic infiltration that resulted in hypercoagulability. Therefore, heparin was used for anticoagulant therapy with intermittent platelet transfusions. To date, no other thrombosis has occurred and the platelets generally reached the normal range.
Glucocorticoids are the first-line therapy for FIP1L1PDGFRA-negative HES and are very effective for decreasing eosinophil counts [7]. INF- $\alpha$, hydroxyurea, and antiIL-5 monoclonal antibodies are considered in case of glucocorticoid resistance. In our case, eosinophil counts decreased gradually with glucocorticoids. However, despite the decrease in the eosinophil counts, the risk for thrombosis recurrence did not disappear as reflected by an intestinal obstruction which may have been related to the thrombosis of the mesenteric vein. Although our patient's eosinophil counts were significantly reduced by glucocorticoid administration, the patient needed emergency operation for the intestinal obstruction. Eosinophil counts do not always seem tomatch with organ damage.

The link between eosinophilia and the thrombotic event is still unclear. One possible reason is the infiltration of eosinophils in involved tissues $[8,9,10]$. A number of cytotoxic substances are then released, including highly cationic molecules such as eosinophil cationic protein, major basic protein, ribonuclease eosinophil-derived neurotoxin, oxidizing molecules such as eosinophil peroxidase and free oxygen radicals, and enzymes such as elastase and collagenase. Eosinophils can also produce lipid mediators such as leukotrienes and prostaglandins. Another reason is the presence of predispositions to thrombosis, such as immobility, genetic hypercoagulability, or advanced atherosclerosis $[4,11,12]$.

In conclusion, HES with thromboembolic events in multiple organs is usually difficult to manage. Therefore, patients should be monitored carefully for the potential complications of the disease, and treatment should be performed according to the situation of each individual patient.

\section{Acknowledgments}

This work was supported by the Tianjin Science and Technology Committee (11JCZDJC18600).

\section{Conflict of Interest Statement}

The authors of this paper have no conflicts of interest, including specific financial interests, relationships, and/ or affiliations relevant to the subject matter or materials included.

\section{References}

1. Klion A. Hypereosinophilic syndrome: current approach to diagnosis and treatment. Annu Rev Med 2009;60:293-306.

2. Kocaturk H, Yilmaz M. Idiopathic hypereosinophilic syndrome associated with multiple intracardiac thrombi. Echocardiography 2005;22:675-676.

3. Kikuchi K, Minami K, Miyakawa H, Ishibashi M. Portal vein thrombosis in hypereosinophilic syndrome. Am J Gastroenterol 2002;97:1274-1275. 
4. Narayan S, Ezughah F, Standen GR, Pawade J, Kennedy CT. Idiopathic hypereosinophilic syndrome associated with cutaneous infarction and deep venous thrombosis. Br J Dermatol 2003;148:817-820.

5. Grigoryan M, Geisler SD, St Louis EK, Baumbach GL, Davis PH. Cerebral arteriolar thromboembolism in idiopathic hypereosinophilic syndrome. Arch Neurol 2009;66:528531.

6. Kobayashi M, Komatsu N, Kuwayama Y, Bandobashi K, Kubota T, Uemura Y, Taguchi H. Idiopathic hypereosinophilic syndrome presenting acute abdomen. Intern Med 2007;46:675-678.

7. Park YM, Bochner BS. Eosinophil survival and apoptosis in health and disease. Allergy Asthma Immunol Res 2010;2:87-101.

8. Liapis H, Ho AK, Brown D, Mindel G, Gleich G. Thrombotic microangiopathy associated with the hypereosinophilic syndrome. Kidney Int 2005;67:1806-1811.
9. Sakuta R, Tomita Y, Ohashi M, Nagai T, Murakami N. Idiopathic hypereosinophilic syndrome complicated by central sinovenous thrombosis. Brain Dev 2007;29:182184.

10. Uemura K, Nakajima M, Yamauchi N, Fukayama M, Yoshida K. Sudden death of a patient with primary hypereosinophilia, colon tumours, and pulmonary emboli. J Clin Pathol 2004;57:541-543.

11. Gümrük F, Gürgey A, Altay C. A case of hypereosinophilic syndrome associated with factor $\mathrm{V}$ Leiden mutation and thrombosis. Br J Haematol 1998;101:208-209.

12. Johnston AM, Woodcock BE. Acute aortic thrombosis despite anticoagulant therapy in idiopathic hypereosinophilic syndrome. J R Soc Med 1998;91:492-493. 